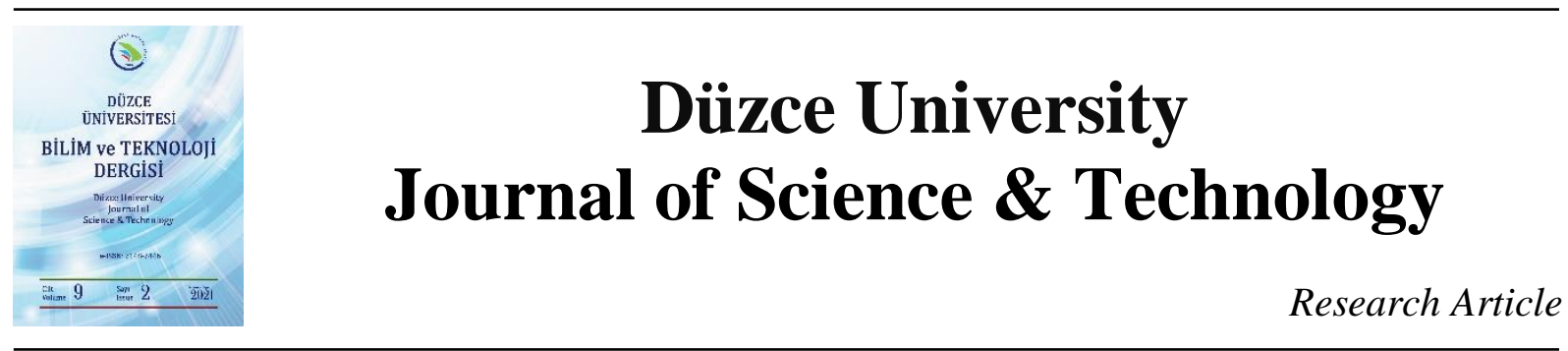

\section{Solidity Optimization for an H-Darrieus Wind Turbine}

\author{
M. Özgün KORUKÇU ${ }^{\mathrm{a}, *}$ \\ ${ }^{a}$ Department of Mechanical Engineering, Faculty of Engineering, Bursa Uludağ University, \\ Bursa, TURKEY \\ * Corresponding author's e-mail address: ozkorukcu@uludag.edu.tr
} DOI: 10.29130/dubited.813917

\begin{abstract}
Solidity is one of the main factors that influence the performance of a wind turbine. The solidity of an H-Darrieus wind turbine is optimized in terms of blade number, chord length, and rotor radius to get the maximum power coefficient using Taguchi L16 (4^3) array. Power coefficient values are calculated by the Double Multiple Stream Tube model by in house built MATLAB code according to Taguchi orthogonal array. The maximum power coefficient is found as 0.4728 for the two-bladed rotor with a chord length of $0.2 \mathrm{~m}$ and a radius of $2 \mathrm{~m}$. Relation of maximum power coefficient respect to blade number, chord length, and rotor radius is derived. Predicted mean values of the maximum power coefficient are in agreement with calculated values. Furthermore, an equation for the maximum power coefficient is obtained for rotor solidity. Derived equations can be useful to estimate the maximum power coefficient values of H-Darrieus wind turbines.
\end{abstract}

Keywords: Vertical Axis Wind Turbine, DMST model, Solidity, Optimization.

\section{Bir H-Darrieus Rüzgar Türbini için Solidite Optimizasyonu}

\begin{abstract}
ÖZET
Solidite bir rüzgar türbini performansını etkileyen ana faktörler arasında yer almaktadır. Bir H-Darrieus rüzgar türbininin maksimum güç katsayısını veren soliditesi kanat sayısı, kord uzunluğu ve rotor yarıçapı cinsinden Taguchi L16 (4^3) dizisi kullanılarak optimize edilmiştir. Güç katsayısı değerlerinin hesaplamasında Taguchi ortogonal dizisine göre MATLAB yardımıyla Çift Çoklu Akım Tüpü modeli için geliştirilmiş kod kullanılmıştır. En yüksek güç katsayısı 0.4728 değeri iki-kanatlı, $0.2 \mathrm{~m}$ kord uzunluğunda ve yarıçapı $2 \mathrm{~m}$ olan rotor için bulunmuştur. En yüksek güç katsayısı değeri için kanat sayısı, kord uzunluğu ve rotor yarıçapı cinsinden bir bağıntı elde edilmiştir. Tahmini ortalama en yüksek güç katsayısı değerleri ile hesaplanan değerler uyum içerisinde bulunmuştur. Ayrıca, en yüksek güç katsayısı için rotor soliditesi cinsinden bir denklem elde edilmiştir. Elde edilen denklemler H-Darrieus rüzgar türbinlerinin en yüksek güç katsayılarını tahmin etmekte kullanılabilir.
\end{abstract}

Anahtar Kelimeler: Dikey Eksenli Rüzgar Türbini, DMST Modeli, Solidite, Optimizasyon 


\section{INTRODUCTION}

After the great oil crisis in the 1970s, countries started to search for alternative energy sources for fossil fuels. These alternative energy sources should be sustainable and renewable. Wind energy is one of these renewable energy sources [1]. Although Horizontal Axis Wind Turbines (HAWT) lead the wind energy market in the last few years, researches for improving the aerodynamic performance of Vertical Axis Wind Turbines (VAWT) are becoming popular [2]. The main parameters that are affecting the aerodynamic performance of VAWT's are; blade profile and rotor geometry, solidity, aspect ratio, tip speed ratio. Aerodynamic performances of wind turbines can be investigated by conducting wind tunnel experiments, CFD calculations, momentum models, and stream-tube models. Wind tunnel experiments give real results, but they are expensive. CFD models try to solve unsteady Navier-Stokes equations, and they are sensitive to grid size, time step, turbulence model, and computer processor capacity. Momentum models use lookup tables of airfoil lift and drag coefficient values for different Reynolds numbers and then calculate forces acting on turbine blades. Stream-tube models are high-speed and convenient to investigate the performance of VAWT [3-6]. Stream tube models are derived from the single-stream tube model [7] and then improved to a multiple stream tube model by Strickland [8]. The double Multiple Stream Tube model (DMST) was enhanced by Paraschivoiu [9].

There are several studies for the optimization of geometrical parameters of H-Darrieus wind turbines. Brusca et al. [10] investigated the effect of aspect ratio (ratio of blade height to rotor radius) on aerodynamic performance for a symmetrical straight bladed wind turbine by using the Multiple Stream Tube Model. According to their study, as the aspect ratio decreases power coefficient increases. Carrigan et al. [11] used a differential evolution algorithm after conducting unsteady CFD calculations to obtain an optimized design for maximum turbine performance. They fixed the tip speed ratio and then changed the airfoil type and solidity to get maximum torque from the rotor. Du et al. [12] made experimental studies to investigate the effect of turbine solidity, blade profile, surface roughness, and aspect ratio on an H-Darrieus wind turbine. Their main focus was on the self-start of the turbine. Their study showed that high turbine solidity, a thick symmetrical blade with a negative low pitch $\left(-2^{\circ}\right)$, is more advantageous than a cambered blade for self-starting. Li et al. [13] used the panel method to investigate the effect of rotor aspect ratio and solidity on a straight-bladed vertical axis wind turbine. First, the solidity is kept at a constant value of 0.0064 , and the aspect ratio is changed. Then by keeping the aspect ratio, they changed the solidity. They stated that solidity has more effect on turbine performance than that of the rotor aspect ratio. Miller et al. [14] did experiments for understanding the solidity and Reynolds number effects on straight-bladed vertical axis wind turbines. Two different turbines were used with a solidity of 0.67 for the three-bladed turbine and solidity of 1.12 for a five-bladed turbine. They concluded that turbine performance is affected by Reynolds number not directly on solidity. Nguyen and Metzger [15] examined thirteen vertical axis wind turbine geometries to find optimum power coefficient for urban areas. Aspect ratio, airfoil type, solidity, and moment of inertia parameters are changed. From all thirteen geometrical combinations, the best power coefficient was obtained for a turbine with an aspect ratio of 1.2, the solidity of 0.12 , and a blade with NACA0015 airfoil. Parra et al. [16] investigated the effect of solidity on vertical axis wind turbines by using CFD. Two different turbines with a solidity of 1 and 1.5 were examined. As a result, they showed that the turbine, with a solidity of 1, has a better power coefficient. Rezaeiha [17] studied the impact of solidity and blade number on vertical axis wind turbine performance. The effect of the blade number and solidity were investigated.

In the present study, the optimum solidity value for a straight-bladed H-Darrieus wind turbine is investigated by using Taguchi method. The blade profile is chosen as NACA0012, blade number, chord length, and rotor radius are changed. The effects of each parameter on the performance of the turbine are presented. The relation of maximum $C_{p}$ means of blade number, chord length, and rotor radius is derived. 


\section{METHOD}

\section{A. DOUBLE MULTIPLE STREAM TUBE MODEL}

In Double Multiple Stream Tube (DMST) model, the rotor consists of stream tubes. Every stream tube receives free stream $(U)$ and, this free stream is divided into upstream $\left(U_{u}\right)$ and downstream $\left(U_{d}\right)$ components. Momentum conservation is applied to the stream tubes. Figure 1 depicts a three-bladed $\mathrm{H}-$ Darrieus rotor.

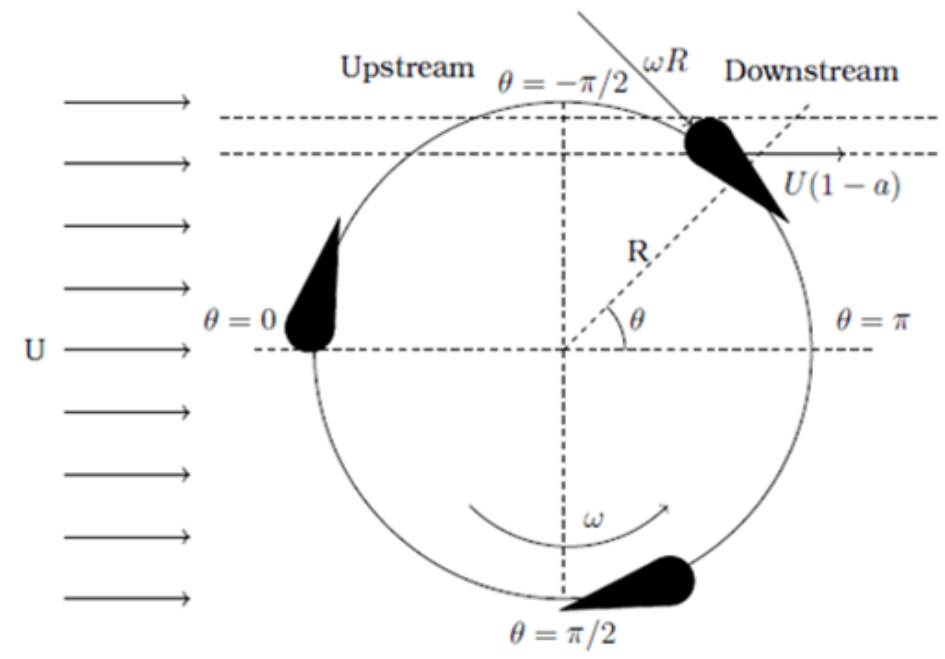

Figure 1. Rotor geometry.

Velocity components on a blade are shown in Figure 2.

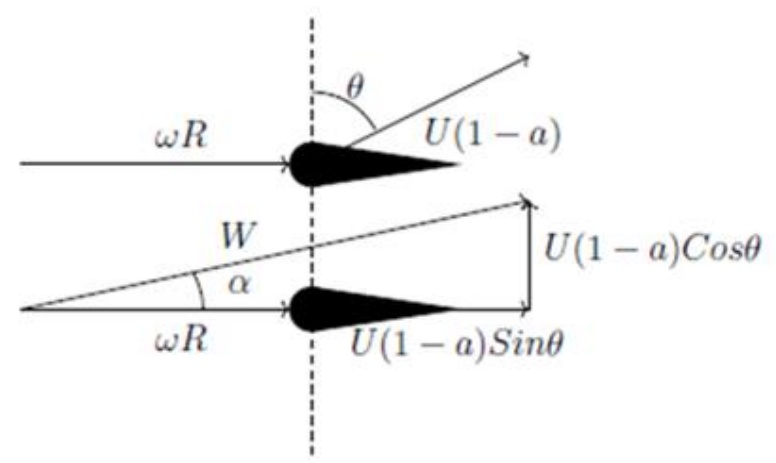

Figure 2. Velocity components.

The rotor solidity is:

$$
\sigma=\frac{N c}{2 R}
$$

The blade number is $N$, chord length is $c$, and the rotor radius is $R$.

The tip speed ratio is:

$$
\lambda=\frac{\omega R}{U}
$$


Angular velocity is $\omega$

Upstream $\left(W_{u}\right)$ and downstream $\left(W_{d}\right)$ relative velocities

$$
\begin{aligned}
& W_{u}=\left(\omega R+U_{u}\left(1-a_{u}\right) \sin \theta\right)^{2}+\left(U_{u}\left(1-a_{u}\right) \cos \theta\right)^{2} \\
& W_{d}=\left(\omega R+U_{d}\left(1-a_{d}\right) \sin \theta\right)^{2}+\left(U_{d}\left(1-a_{d}\right) \cos \theta\right)^{2}
\end{aligned}
$$

Upstream $\left(a_{u}\right)$ and downstream $\left(a_{d}\right)$ are axial induction factors.

Upstream $\left(\alpha_{u}\right)$ and downstream $\left(\alpha_{d}\right)$ are angles of attack.

$$
\begin{aligned}
& \alpha_{u}=\frac{\left(U_{u}\left(1-a_{u}\right) \cos \theta\right)}{\left(\omega R+U_{u}\left(1-a_{u}\right) \sin \theta\right)} \\
& \alpha_{d}=\frac{\left(U_{d}\left(1-a_{d}\right) \cos \theta\right)}{\left(\omega R+U_{d}\left(1-a_{d}\right) \sin \theta\right)}
\end{aligned}
$$

Thrust forces can be calculated as

$$
\begin{gathered}
F_{u}=\frac{N c}{8 \pi R} \frac{W_{u}^{2}}{U_{u}^{2}} \sec \theta\left(C_{n_{u}} \cos \theta-C_{t_{u}} \sin \theta\right) \\
F_{d}=\frac{N c}{8 \pi R} \frac{W_{d}^{2}}{U_{d}^{2}} \sec \theta\left(C_{n_{d}} \cos \theta-C_{t_{d}} \sin \theta\right)
\end{gathered}
$$

Normal, tangential, lift, and drag coefficients are $C_{n}, C_{t}, C_{l}, C_{d}$, respectively. $C_{l}, C_{d}$ coefficients are computed by XFOIL software for the angle of attack values. Tangential and normal coefficients can be calculated by using lift and drag coefficients:

$$
\begin{aligned}
& C_{n}=C_{l} \cos \alpha+C_{d} \sin \alpha \\
& C_{t}=C_{l} \sin \alpha-C_{d} \cos \alpha
\end{aligned}
$$

The upstream and downstream tangential forces are calculated as:

$$
\begin{aligned}
& F t_{u}=C t_{u}\left(\frac{W_{u}}{U}\right)^{2} \\
& F t_{d}=C t_{d}\left(\frac{W_{d}}{U}\right)^{2}
\end{aligned}
$$

The torque of every single stream-tube $\left(Q_{i}\right)$ is calculated for a unit length of the blade and then used to obtain the total torque $\left(Q_{T}\right)$ of the rotor.

$$
\begin{aligned}
& Q_{i}=\frac{1}{2} \frac{N c \rho}{2 \pi\left(U_{u}+U_{d}\right)}\left[\begin{array}{l}
W_{u}^{2} U_{d}\left(C_{t_{u}} R+C_{n_{u}} \frac{c}{4}\right) \\
+W_{d}^{2} U_{u}\left(C_{t_{d}} R+C_{n_{d}} \frac{c}{4}\right)
\end{array}\right] \\
& Q_{T}=L \sum_{\theta=-\pi / 2}^{\theta=\pi / 2} Q_{i}
\end{aligned}
$$

Where $\mathrm{L}$ is the length of the rotor, and $\rho$ is the density. 
Generated power $(P)$ and the power coefficient $\left(C_{p}\right)$ of the rotor defined as:

$$
\begin{aligned}
& P=Q_{T} \omega \\
& C_{p}=\frac{P}{1 / 2 \rho A U^{3}}
\end{aligned}
$$

Free stream velocity $(U)$ and air density $(\rho)$ are taken as $10 \mathrm{~m} / \mathrm{s}$ and $1.225 \mathrm{~kg} / \mathrm{m}^{3}$, respectively. Power coefficient values are calculated with MATLAB by using the DMST model.

\section{B. TAGUCHI DESIGN}

In the optimization of the solidity, the Taguchi method is used. Solidity parameters are defined as blade number $N$, chord length $c$, and rotor radius $R$. For each parameter; four levels are chosen. Parameters and levels are given in Table 1. For the design of experiments, Taguchi L16 $\left(4^{\wedge} 3\right)$ orthogonal array is used. Taguchi L16 (4^3) orthogonal array is represented in Table 2. $C_{p}$ values from DMST results are converted to signal to noise ratio $(\mathrm{S} / \mathrm{N})$. In order to get the maximum $C_{p}$ value, the larger-the-better criterion is chosen. The maximum criterion for $\mathrm{S} / \mathrm{N}$ ratio is defined as [18]

$$
S / N_{\max }=-10 \log \left(\frac{1}{n} \sum_{i=1}^{n} \frac{1}{y_{i}^{2}}\right)
$$

Here $n$ is the test number, and $y_{i}$ is the simulation result number for performance characteristics.

Table 1. Solidity parameters and levels used in the study.

\begin{tabular}{lllll}
\hline Parameter & Level 1 & Level 2 & Level 3 & Level 4 \\
\hline Blade Number & 2 & 3 & 4 & 5 \\
\hline Chord Length (m) & 0.2 & 0.3 & 0.4 & 0.5 \\
\hline Rotor Radius (m) & 0.5 & 1 & 1.5 & 2 \\
\hline
\end{tabular}

\section{RESULTS}

Validation of the DMST model is made by comparison of experimental data from Kjellin et al. [19] in which a rotor has three blades, airfoil type of NACA0021, chord length of $0.25 \mathrm{~m}$, blade height of $5 \mathrm{~m}$ and rotor radius of $3 \mathrm{~m}$ was used. As seen from Figure 3, up to $\lambda=3$ there is a good agreement with experimental data but after that value, the DMST model overestimates the results and this is due to the two-dimensional approach of the model. 


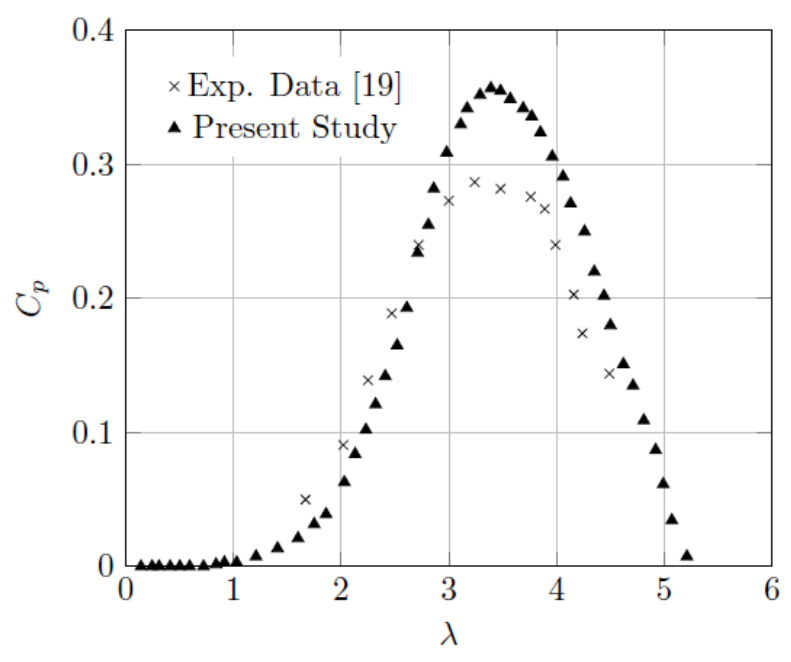

Figure 3. Validation of the DMST model.

The maximum power coefficient values obtained from 16 DMST calculations are processed with Minitab18 software, ANOVA, and regression analyses are calculated.

Table 3 shows the calculated maximum power coefficient values by using Taguchi L16 $\left(4^{\wedge} 3\right)$ orthogonal array and $S / N$ ratios. The maximum $S / N$ ratio represents the maximum power coefficient value. According to the mean $S / N$ ratio analysis given in Figure 4, the maximum power coefficient value can be obtained by using the maximum $S / N$ ratio value of each parameter. As seen from Figure 4 , the twobladed rotor with a chord length of $0.2 \mathrm{~m}$ and a radius of $2 \mathrm{~m}$ will give the maximum power coefficient. When these parameters are used in the DMST model power coefficient is found as 0.4728 . Increasing the blade number and chord length have adverse effects on the power coefficient but increasing the rotor radius has a positive impact on the power coefficient.

ANOVA method reveals the importance of all factors and interactions of parameters within each other. ANOVA method also defines the influence ratios of parameters on the results. Table 4 represents the ANOVA results of factors, their contributions, and probability values. According to Table 4, all factors are significantly important $(p<0.05)$. The contributions of parameters on the power coefficient are given in Figure 5. As seen from Figure 5, the most influential parameter on the power coefficient is the rotor radius, with $56.85 \%$, following chord length with $24 \%$, and the number of blades with $17 \%$.

Table 2. Taguchi L16 (4^3) orthogonal array.

\begin{tabular}{ccc}
\hline $\boldsymbol{N}$ & $\boldsymbol{c}(\boldsymbol{m})$ & $\boldsymbol{R}(\boldsymbol{m})$ \\
\hline 2 & 0.2 & 0.5 \\
2 & 0.3 & 1.0 \\
2 & 0.4 & 1.5 \\
2 & 0.5 & 2.0 \\
3 & 0.2 & 1.0 \\
3 & 0.3 & 0.5 \\
3 & 0.4 & 2.0 \\
3 & 0.5 & 1.5 \\
4 & 0.2 & 1.5 \\
4 & 0.3 & 2.0 \\
4 & 0.4 & 0.5 \\
4 & 0.5 & 1.0 \\
5 & 0.2 & 2.0 \\
5 & 0.3 & 1.5 \\
5 & 0.4 & 1.0 \\
5 & 0.5 & 0.5 \\
\hline
\end{tabular}


Table 3. The maximum power coefficient values and calculated $S / N$ ratios.

\begin{tabular}{ccc}
\hline Orthogonal Array & $\boldsymbol{C}_{\boldsymbol{p} \text { Max }}$ & $\boldsymbol{S} / \boldsymbol{N}$ Ratio \\
\hline 111 & 0.306486 & -10.2718 \\
122 & 0.376253 & -8.4904 \\
133 & 0.398384 & -7.9940 \\
144 & 0.397600 & -8.0111 \\
212 & 0.392760 & -8.1175 \\
221 & 0.131797 & -17.6019 \\
234 & 0.392760 & -8.1175 \\
243 & 0.269332 & -11.3942 \\
313 & 0.419750 & -7.5402 \\
324 & 0.401013 & -7.9368 \\
331 & 0.045692 & -26.8032 \\
342 & 0.129043 & -17.7853 \\
414 & 0.418369 & -7.5688 \\
423 & 0.288216 & -10.8056 \\
432 & 0.139275 & -17.1225 \\
441 & 0.027337 & -31.2651 \\
\hline
\end{tabular}

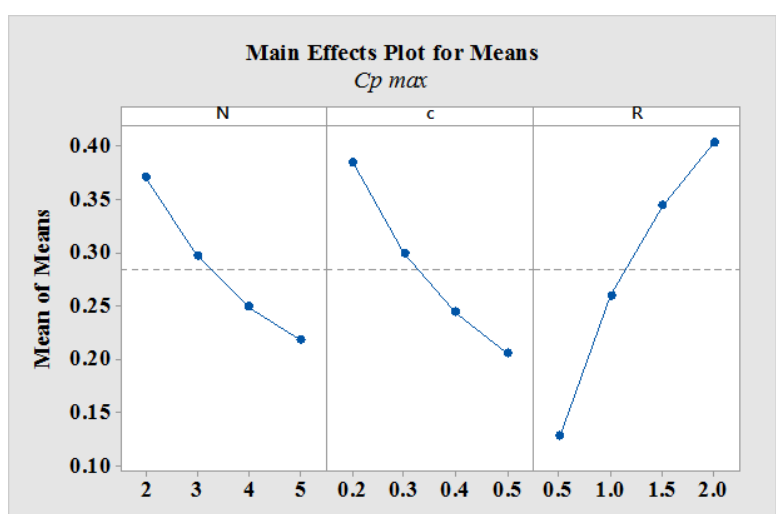

Figure 4. S/N ratios for different solidity parameters.

Table 4. ANOVA table for $S / N$ ratios of maximum power coefficient values.

\begin{tabular}{cccccccc}
\hline Source & DF & Seq SS & Contribution & Adj SS & Adj MS & F-Value & P-Value \\
\hline $\mathrm{N}$ & 3 & 0.052201 & $17.41 \%$ & 0.052201 & 0.017400 & 20.25 & 0.001534 \\
$\mathrm{c}$ & 3 & 0.072041 & $24.03 \%$ & 0.072041 & 0.024014 & 27.95 & 0.000635 \\
$\mathrm{R}$ & 3 & 0.170457 & $56.85 \%$ & 0.170457 & 0.056819 & 66.13 & 0.000055 \\
Error & 6 & 0.005155 & $1.72 \%$ & 0.005155 & 0.000859 & & \\
Total & 15 & 0.299854 & $100.00 \%$ & & & & \\
\hline
\end{tabular}

DF: Degree of Freedom Seq SS: Sequential Sum of Squares Adj SS: Adjusted Sum of Squares Adj MS: Adjusted Mean of Squares F: Statistical Value P: Probability Value 


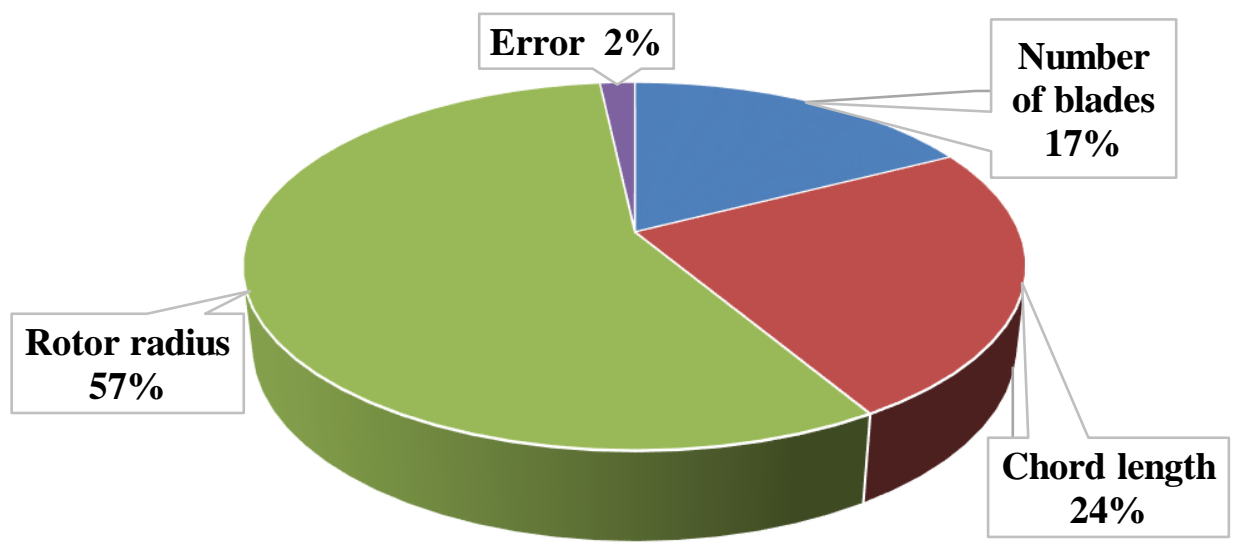

Figure 5. Percentage of contributions of the solidity parameters on the power coefficient.

The relation for maximum power coefficient in terms of blade number, chord length, and rotor radius is derived by using the linear regression method. As seen in Equation 18 regression coefficient of the derived relation is $r^{2}=0.9513$. This result states that the derived equation is reliable.

$$
C_{p \max }=0.4387-0.05019 N-0.5908 c+0.1817 R\left(r^{2}=0.9513\right)
$$

Calculated maximum power coefficient values are compared with predicted mean values by using the quadratic regression model. Figure 6 shows the comparison of computed power coefficient values and predicted mean values. Quadratic equation for maximum power coefficient respect to predicted mean values are derived in Equation 19, and it is found that there is a good correlation $\left(r^{2}=0.988\right)$ between them.

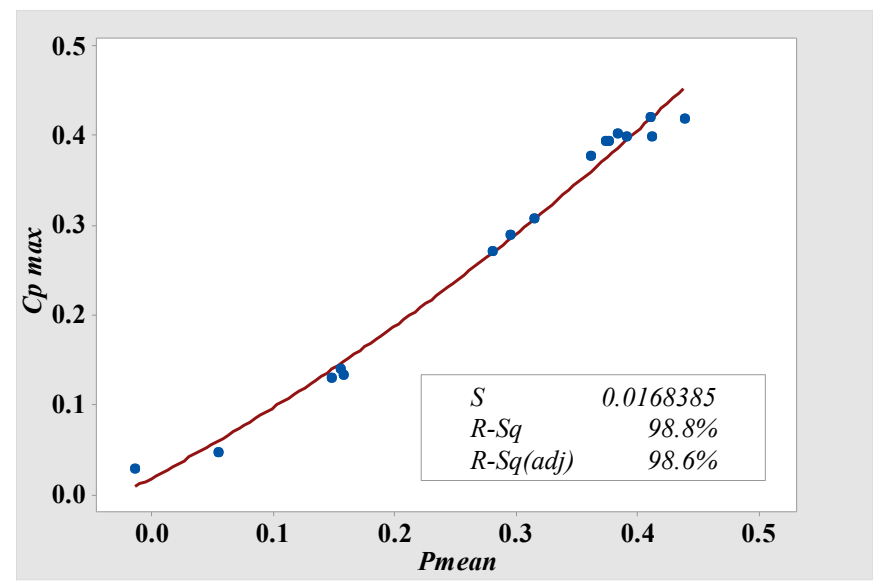

Figure 6. Quadratic regression analysis for predicted mean and calculated maximum power coefficient results.

$$
C_{p \max }=0.01841+0.7218 \text { Pmean }+0.6121 \text { Pmean }^{2}\left(r^{2}=0.988\right)
$$

The variation of calculated maximum power coefficient values with solidity is presented in Figure 7. As seen in Figure 7, maximum power coefficient values decrease with increasing rotor solidity. Equation 19 represents the relationship between the maximum power coefficient and rotor solidity. The regression coefficient of Equation 19 is found as $r^{2}=0.992$. 


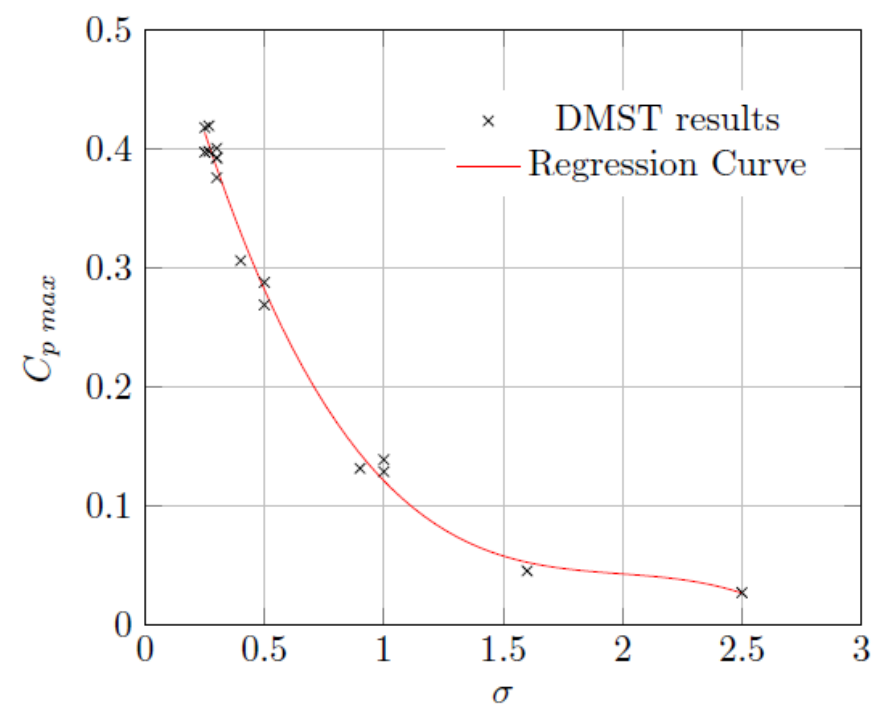

Figure 7. Variation of calculated maximum power coefficient with solidity.

$$
C_{p \max }=-0.0656 \sigma^{3}+0.3915 \sigma^{2}-0.7936 \sigma+0.5891\left(r^{2}=0.992\right)
$$

\section{CONCLUSION}

The solidity of a straight-bladed H-Darrieus wind turbine with the NACA0012 blade profile is optimized. Blade number, chord length, rotor radius factors with four levels, and Taguchi L16 $\left(4^{\wedge} 3\right)$ orthogonal array are used for optimization. The maximum power coefficient values are calculated with the Double-Multiple-Stream-Tube model (DMST) by using MATLAB code. Obtained results are processed with Minitab18 software for optimization, ANOVA, and regression analyses. Optimization results showed that the maximum power coefficient value of 0.4728 could be obtained for a turbine of a two-bladed rotor with a chord length of $0.2 \mathrm{~m}$ and a radius of $2 \mathrm{~m}$. ANOVA results revealed that the most influential factor in solidity is rotor radius with $57 \%$, following chord length with $24 \%$ and blade number with $17 \%$. Equation of the maximum power coefficient for rotor radius, chord length, and blade number is derived with a good regression coefficient of $r^{2}=0.9513$. Another maximum power coefficient equation is obtained for solidity value with a regression coefficient of $r^{2}=0.992$.

This study can be a guide for the designers and producers of H-Darrieus wind turbines. DMST model is fast, useful, but it should be remembered that the model does not take 3D, wake interactions among the blades, and turbulence effects. In order to get more accurate results, DMST calculations should be supported by wind turbine experiments.

\section{REFERENCES}

[1] E. K. Akpinar, "A statistical investigation of wind energy potential," Energy Sources, Part A Recover. Util. Environ. Eff., vol. 28, no. 9, pp. 807-820, 2006.

[2] S. Mathew, Wind Energy Fundamentals, Resource Analysis and Economics, Berlin Heidelberg, Netherlands: Springer-Verlag 2006.

[3] G. Bedon, U. S. Paulsen, H. A. Madsen, F. Belloni, M. R. Castelli, and E. Benini, “Aerodynamic Benchmarking of the Deepwind Design,” Energy Procedia, vol. 75, pp. 677-682, 2015. 
[4] J. Chen, L. Chen, H. Xu, H. Yang, C. Ye, and D. Liu, "Performance improvement of a vertical axis wind turbine by comprehensive assessment of an airfoil family," Energy, vol. 114, pp. 318-331, 2016.

[5] G. Bedon, S. De Betta, and E. Benini, "Performance-optimized airfoil for Darrieus wind turbines," Renew. Energy, vol. 94, pp. 328-340, 2016.

[6] M. Abdul Akbar and V. Mustafa, "A new approach for optimization of Vertical Axis Wind Turbines," J. Wind Eng. Ind. Aerodyn., vol. 153, pp. 34-45, 2016.

[7] R. J. Templin, "Aerodynamic performance theory for the NRC vertical-axis wind turbine," Natl. Res. Counc. Canada, 1974.

[8] J. Strickland, "The Darrieus Turbine: A Performance Prediction Model Using Multiple Stream Tubes,” Technical Report SAND75-041, Sandia National Laboratories, Albuquerque, 1975.

[9] I. Paraschivoiu, "Double-Multiple Streamtube Model for Darrieus Wind Turbines," Tech. Rep., Institute de recherché d’Hydro-Québec, Canada, 1983.

[10] S. Brusca, R. Lanzafame, and M. Messina, "Design of a vertical-axis wind turbine: how the aspect ratio affects the turbine's performance," Int. J. Energy Environ. Eng., vol. 5, no. 4, pp. 333-340, 2014.

[11] T. J. Carrigan, B. H. Dennis, Z. X. Han, and B. P. Wang, "Aerodynamic Shape Optimization of a Vertical-Axis Wind Turbine Using Differential Evolution," ISRN Renew. Energy, vol. 2012, pp. 1$16,2012$.

[12] L. Du, G. Ingram, and R. G. Dominy, "Experimental study of the effects of turbine solidity, blade profile, pitch angle, surface roughness, and aspect ratio on the H-Darrieus wind turbine selfstarting and overall performance," Energy Sci. Eng., vol. 7, no. 6, pp. 2421-2436, 2019.

[13] H. Zhu, W. Hao, C. Li, and Q. Ding, "Numerical study of effect of solidity on vertical axis wind turbine with Gurney flap," J. Wind Eng. Ind. Aerodyn., vol. 186, pp. 17-31, 2019.

[14] M. A. Miller, S. Duvvuri, W. D. Kelly, and M. Hultmark, "Rotor solidity effects on the performance of vertical-axis wind turbines at high Reynolds numbers," J. Phys. Conf. Ser., vol. 1037, no. 5, 2018.

[15] L. Nguyen and M. Metzger, "Optimization of a vertical axis wind turbine for application in an urban/suburban area," J. Renew. Sustain. Energy, vol. 9, no. 4, 2017.

[16] M. T. Parra-Santos, C. N. Uzarraga, A. Gallegos, and F. Castro, "Influence of Solidity on Vertical Axis Wind Turbines," Int. J. Appl. Math. Electron. Comput., vol. 3, no. 3, p. 215, 2015.

[17] A. Rezaeiha, H. Montazeri, and B. Blocken, "Towards optimal aerodynamic design of vertical axis wind turbines: Impact of solidity and number of blades," Energy, vol. 165, pp. 1129-1148, 2018.

[18] G. Taguchi, S. Chowdhury, and Y. Wu, Taguchi's Quality Engineering Handbook, Wiley\&Sons, 2004.

[19] J. Kjellin, F. Bülow, S. Eriksson, P. Deglaire, M. Leijon, and H. Bernhoff, "Power coefficient measurement on a $12 \mathrm{~kW}$ straight bladed vertical axis wind turbine", Renew. Energy, vol. 36, pp. 30503053, 2011. 